\title{
Reduction of Electrical Contact Resistance between Components of Solid Oxide Fuel Cells
}

\author{
Kazutoshi MURATA and Masateru SHIMOTSU* \\ Tamano Technology Center, Mitsui Engineering \& Shipbuilding Co., Ltd., 3-16-1, Tamahara, Tamano-shi, Okayama 706-0014 \\ *Faculty of Engineering, Tokushima Bunri University, 1314-1, Shido, Sanuki-shi, Kagawa 769-2193
}

\author{
固体電解質型燃料電池構成部材間の電気接触抵抗の低減 \\ 村田和俊 · 下津正輝* \\ 三井造船 (株)技術本部機械制御技術開発センター，706-0014 岡山県玉野市玉原 3-16-1 \\ *徳島文理大学工学部機械電子工学科, 769-2193 香川県さ妨志度 1314-1
}

\begin{abstract}
Aiming at lowering contact resistance between SOFC components, we produced an Air-Side Electrical Connector (ASEC) which deforms easily under compressive load at high temperature. The ASEC was prepared by soaking a cloth of a carbon fiber with a $\left(\mathrm{La}_{0.85} \mathrm{Sr}_{0.15}\right)_{0.85} \mathrm{MnO}_{3}$ (LSM) slurry and firing at $1200^{\circ} \mathrm{C}$. The porous ASEC was then pressed at a temperature of $1500^{\circ} \mathrm{C}$. It deformed easily, and its thickness changed to be $38 \%, 46 \%$, and $58 \%$ of the pre-deformed one under a stress of $98 \mathrm{kPa}, 49 \mathrm{kPa}$, and $20 \mathrm{kPa}$, respectively. Dense LSM bulks or $\left(\mathrm{La}_{0.75} \mathrm{Ca}_{0.30}\right) \mathrm{Cr}_{0.95} \mathrm{O}_{3}$ (LCC) bulks were bonded with the ASEC as an intermediate material at $1500^{\circ} \mathrm{C}$. The contact resistances at $1000^{\circ} \mathrm{C}$ in air between the LSM and the ASEC, and between the LCC and the ASEC were $1.1 \mathrm{~m} \Omega \mathrm{cm}^{2}$ and $4.2 \mathrm{~m} \Omega \mathrm{cm}^{2}$, respectively, at the bonding condition of $98 \mathrm{kPa}$. The difference was attributed to the formation of a new perovskite phase which has high electrical resistance at the interface between the LCC and the ASEC. However, the estimated I-R drop at the contact of LSM/LCC under the cell current density of $0.3 \mathrm{~A} \mathrm{~cm}^{-2}$ was $4 \mathrm{mV}$, an efficiently low value for practical use.
\end{abstract}

[Received March 18, 2002; Accepted December 19, 2002]

Key-words : SOFC, LSM, Contact resistance

\section{Introduction}

Solid Oxide Fuel Cells (SOFC) ${ }^{1)-4}$ has attractive features, such as high energy conversion efficiency, low emission of pollutant gases, no noise, and high flexibility for fuel selection. We have developed planar type ${ }^{5)-9)}$ SOFC, aiming at higher power density and mass productivity. Figure 1 shows our ceramic gas separator. Button-shaped $\mathrm{LaCrO}_{3}$ current passages ${ }^{10)}$ are placed on $\mathrm{MgO}-\mathrm{MgAl}_{2} \mathrm{O}_{4}$ separator plate. These smaller passages are very effective for

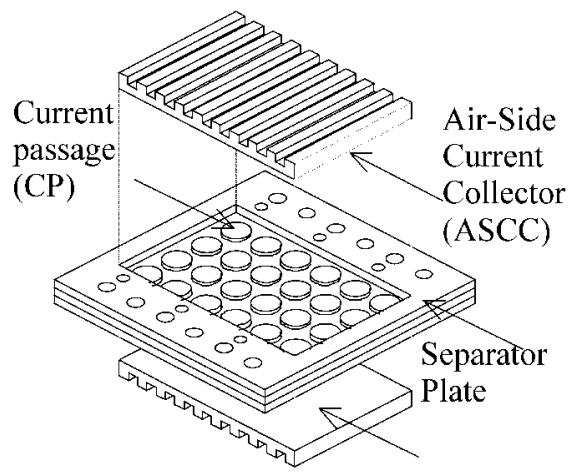

Fuel-Side Current Collector(FSCC)

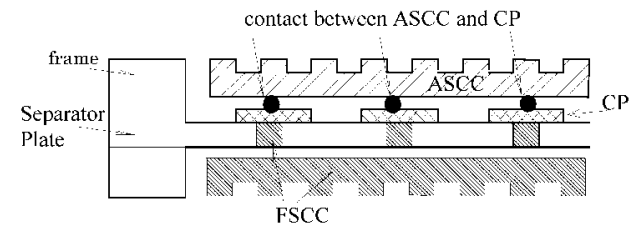

Fig. 1. Schematic view of the ceramic gas separator. lowering manufacturing cost, and suppressing a bowing problem ${ }^{11)}$ under the gradient of oxygen partial pressure.

This structure of the separator divides the cell current into twenty four (24) $\mathrm{LaCrO}_{3}$ current passages. The current density in the button-shaped $\mathrm{LaCrO}_{3}$ is much higher than the one in the plate type $\mathrm{LaCrO}_{3}$. To obtain excellent stack performance, the uniform and reliable electrical contact between the current passage and a current collector is needed.

In this work, we focused on the electrical contact between a $\left(\mathrm{La}_{0.85} \mathrm{Sr}_{0.15}\right)_{0.85} \mathrm{MnO}_{3}$ (LSM) current collector and a $\left(\mathrm{La}_{0.75} \mathrm{Ca}_{0.30}\right) \mathrm{Cr}_{0.95} \mathrm{O}_{3}$ (LCC) current passage. To obtain a good contact, we prepared an Air-Side Electrical Connector (ASEC) which deformed easily like a sponge at the elevated temperature. The ASEC was sandwiched between the LSM bulks or the LCC bulks, and they were bonded under the compressive stress at high temperature. The thickness change during the bonding process was monitored. The contact resistances between the LSM and the ASEC, and that between the LCC and the ASEC were evaluated.

\section{Experimental}

The flow of the sample preparation is shown in Fig. 2. The ASEC is made of $\left(\mathrm{La}_{0.85} \mathrm{Sr}_{0.15}\right)_{0.85} \mathrm{MnO}_{3}$ (LSM). Lanthanum acetate (Mitsuwa Chemical Co., Ltd., Extra Pure), Sr acetate (Kanto Chemical Co., Ltd.), Mn acetate (Kanto Chemical Co., Ltd.) were used as starting materials. They were weighed and mixed in water with a ball milling machine for $24 \mathrm{~h}$. They were dried, decomposed at $400^{\circ} \mathrm{C}$ for an hour, then ground, pressed, and fired at $1200^{\circ} \mathrm{C}$ for $5 \mathrm{~h}$. The fired body was ground into the powder. The LSM slurry was obtained by mixing the LSM powder, a binder, a plasticizer and solvent. A felt of the carbon fiber (Nippon Carbon Co., Ltd., GF-20) which was $3 \mathrm{~mm}$ in thickness was used as a pore-former. The felt was soaked into the LSM slurry in a vacuum vessel. The felt was dried, cut into the size of $25 \mathrm{~mm}$ in diameter, then fired at $1200^{\circ} \mathrm{C}$. A porous 


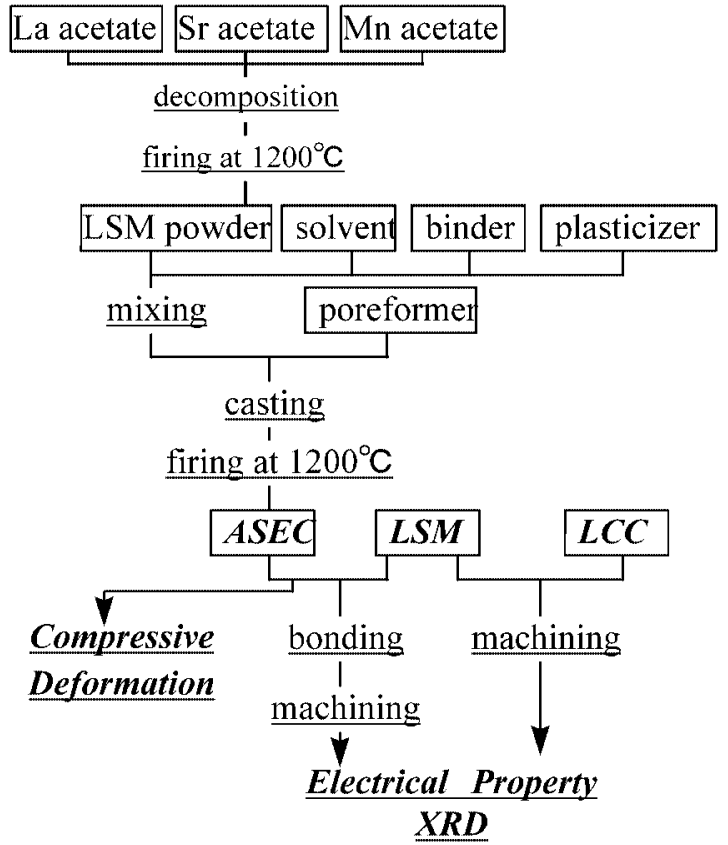

Fig. 2. Flow chart for the sample preparation.

ASEC was obtained. To evaluate deformations of the ASEC under the compressive stress at the elevated temperature, the ASEC was treated as following. The ASECs were sandwiched between the dense LSM bulks $(\phi 25 \mathrm{~mm} \times 15$ $\mathrm{mm})$. The sandwiches were set in an electric furnace with the different compressive stress; $20 \mathrm{kPa}, 49 \mathrm{kPa}$, and 98 $\mathrm{kPa}$. The sandwiched were heated up and held at $1000^{\circ} \mathrm{C}$ for one hour and cooled down. Then they were heated up again to the temperature which was $50^{\circ} \mathrm{C}$ higher than the former heat treatment. As a final heat treatment, they were held at $1500^{\circ} \mathrm{C}$ for one hour. Their thickness was measured after each heat treatment.

The bonding test was carried out with the two plates of the ASEC and the dense materials. One plate of the ASEC was sandwiched between dense LSM bulks $(\phi 25 \mathrm{~mm} \times 15$ $\mathrm{mm}$ ) and the other was sandwiched between dense LCC bulks ${ }^{12), 13)}(\phi 25 \mathrm{~mm} \times 15 \mathrm{~mm})$. The LSM slurry was screen printed on the surfaces of the LSM and the LCC as a bonding agent. They were bonded at the different compressive stress of $20 \mathrm{kPa}, 49 \mathrm{kPa}$, and $98 \mathrm{kPa}$ for five hours at $1500^{\circ} \mathrm{C}$ in air. The bonded was machined into the sizes of $3 \times 3 \times 20 \mathrm{~mm}^{3}$ for the sample A and B as is shown in Fig. 3 . The dense LSM and the LCC were also machined into the size of $2 \times 2 \times 20 \mathrm{~mm}^{3}$ for the sample $\mathrm{C}$ and $\mathrm{D}$. Their electrical conductivity was measured in air with the $\mathrm{DC}$ four probe method at the temperature range between $700^{\circ} \mathrm{C}$ and $1000^{\circ} \mathrm{C}$. The distance between the probes were $10 \mathrm{~mm}$ and the sample current was $100 \mathrm{~mA}$.

To evaluate the chemical stability at the interface between the LSM and the LCC, their powders were mixed at the mass ratio of $1: 1$, then pressed and sintered at $1500^{\circ} \mathrm{C}$ for five hours. The sintered body was analyzed by X-ray diffraction for detecting reaction products. In addition, it was machined into the size of $2 \times 2 \times 20 \mathrm{~mm}^{3}$ (sample E) for electrical conductivity measurement.

\section{Results and discussion}

The deformations of the ASEC under the compressive stress at the elevated temperature were evaluated. The results were shown in Fig. 4. The vertical axis denotes the
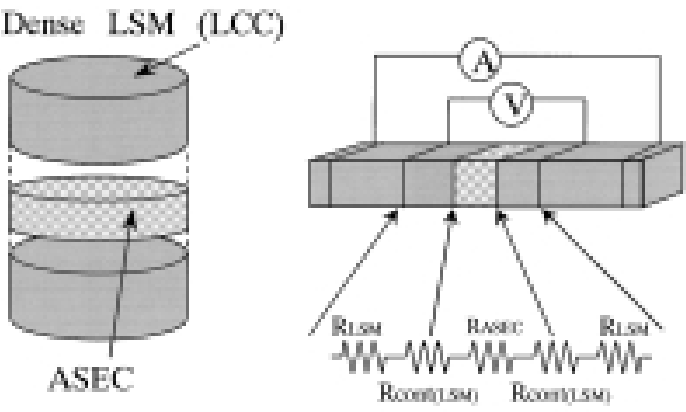

RcontLLss $=0.5$ (Rall-R.sm)

Rcoot(L.SM): contact resistance between the LSM and the ASEC

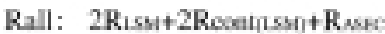

Resu: Resistance of the LSM

Fig. 3. Schematic view of the sample preparation for contact resistance measurement.

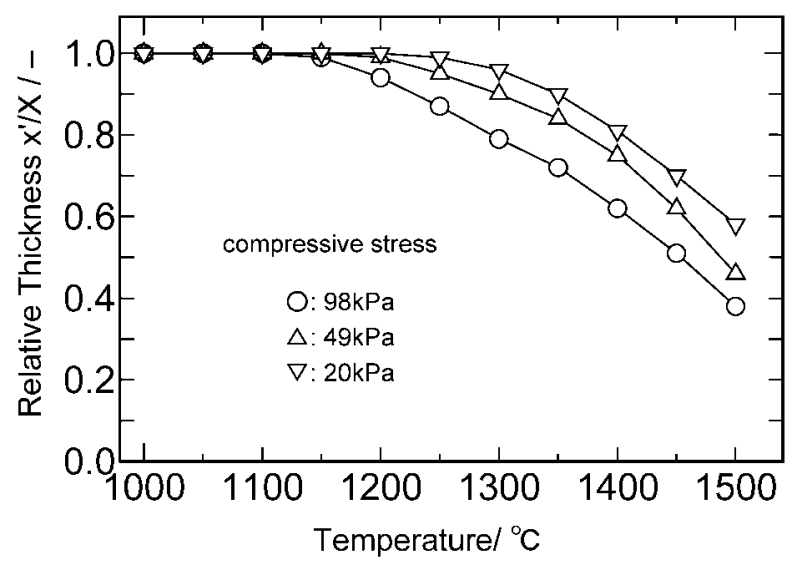

Fig. 4. Thickness change of the air-side electrical connector under the different compressive load at high temperature.

thickness which was normalized with the thickness of precompression. At the temperature lower than $1100^{\circ} \mathrm{C}$, the thickness did not change at the compressive stress of 20 $\mathrm{kPa}, 49 \mathrm{kPa}$, and $98 \mathrm{kPa}$. The sample started being deformed at $1200^{\circ} \mathrm{C}$ at the stress of $98 \mathrm{kPa}$, and its thickness changed to be $38 \%$ of the former one after $1500^{\circ} \mathrm{C}$ treatment. The deformation started at $1250^{\circ} \mathrm{C}$ and $1300^{\circ} \mathrm{C}$ at the compressive stress of $49 \mathrm{kPa}$ and $20 \mathrm{kPa}$, respectively. Their thickness changed to be $46 \%$ and $58 \%$, respectively. The porosities of the samples after $1500^{\circ} \mathrm{C}$ treatment were examined. Their densities were calculated with their sizes and weights. The density of $\left(\mathrm{La}_{0.85} \mathrm{Sr}_{0.15}\right)_{0.85} \mathrm{MnO}_{3}$ measured by using a pycnometer was $6.20 \times 10^{3} \mathrm{~kg} \mathrm{~m}^{-3}$. With the measured density, their porosities were calculated to be $57 \%, 46 \%$, and $35 \%$ at the compressive stress of $20 \mathrm{kPa}, 49$ $\mathrm{kPa}$, and $98 \mathrm{kPa}$, respectively. Figure 5 shows the cross section of the ASEC which was compressed at $1500^{\circ} \mathrm{C}$ and 98 $\mathrm{kPa}$. Near the edge of ASEC, compressed and non-compressed parts were observed. These photographs prove the large deformation of the ASEC. This deformation should be very effective for obtaining the uniform and reliable contact shown in Fig. 1.

Figure 6 and Table 1 show the electrical conductivity ${ }^{12)}{ }^{-15}$ ) of the sample $\mathrm{A}$ and $\mathrm{C}$ at different temperatures. The sample A was prepared by bonding the LSM and the 


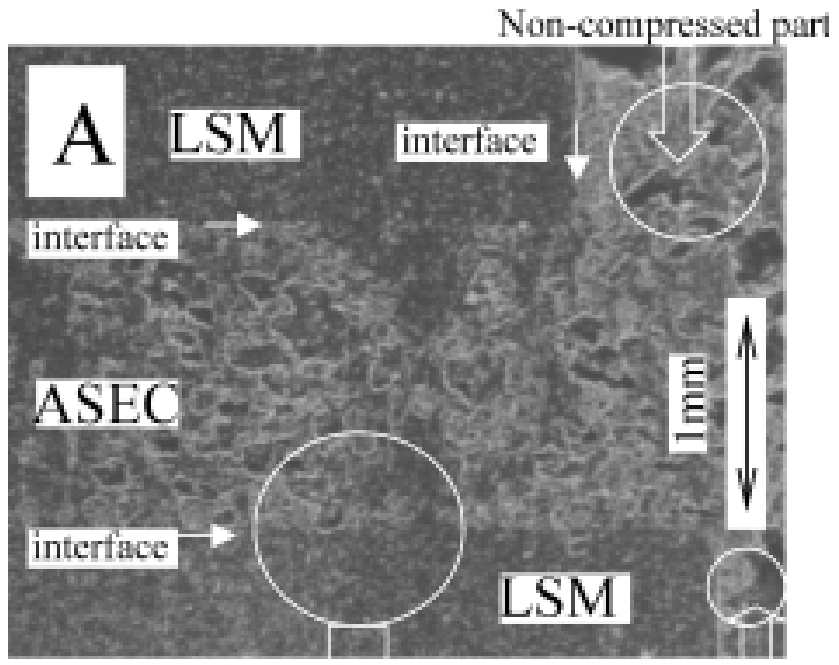

Non-compressed part

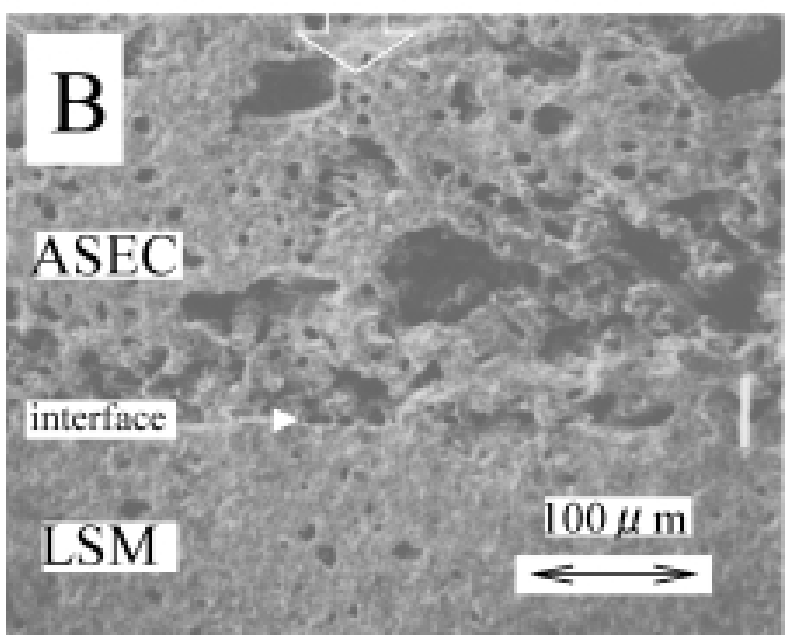

Fig. 5. Cross sections of the bonded interface between the LSM and the ASEC. Photo B (SEM image) is an enlarged part of photo A (optical microscope image).

ASEC, while the sample C was the LSM only. The sample $\mathrm{A}^{7)}$ had the conductivity of $160 \mathrm{~S} \mathrm{~cm}^{-1}$ and the activation energy of $11.7 \mathrm{~kJ} \mathrm{~mol}^{-1}$, which were almost the same as the sample $\mathrm{C}$ had. It suggests that the interface between the LSM and the ASEC had a negligibly low contact resistance. On the other hand, the sample B which was prepared by bonding the LCC and the ASEC, had the lower conductivity of $10 \mathrm{~S} \mathrm{~cm}^{-1}$ and the higher activation energy of $20.3 \mathrm{~kJ}$ $\mathrm{mol}^{-1}$ as is shown in Fig. 7. From these data, it may be inferred that there was a chemical product at the interface between the LCC and the ASEC. In a previous paper, ${ }^{8)}$ we reported that the element of $\mathrm{Ca}$ and $\mathrm{Cr}$ in $(\mathrm{LaCa}) \mathrm{CrO}_{3}$ diffuse into ( $\mathrm{LaSr}$ ) $\mathrm{MnO}_{3}$ beyond their interface during the high temperature bonding. The chemical composition of the components near the interface would be changed. To simulate the interface, LSM and LCC powders were mixed and fired. The fired body was examined by X-ray diffraction. The result was shown in Fig. 8. The mixture had no other phases except for a perovskite one. Its lattice constant was between those of LSM and LCC. The conductivity of the mixture was also evaluated and shown with the symbol $\nabla$ in the Fig. 7. The mixture had the lower conductivity than LSM and LCC. Its activation energy was $28.3 \mathrm{~kJ} \mathrm{~mol}^{-1}$, much higher than that of LSM and LCC.

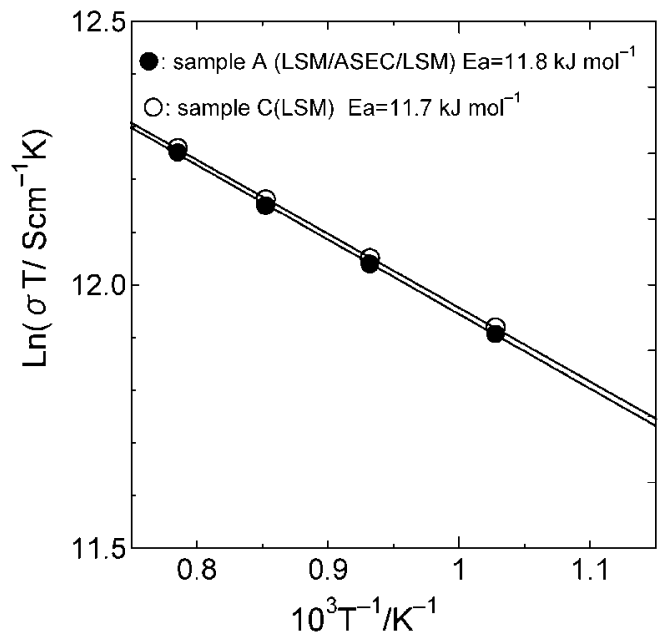

Fig. 6. Electrical conductivity of the samples A and C. The sample A is prepared by bonding the dense LSM bulks with the ASEC as an insert layer. The sample $\mathrm{C}$ is made of the dense LSM.

Table 1. Density and Electrical Conductivity at $1000^{\circ} \mathrm{C}$

\begin{tabular}{ccccc}
\hline Sample & Material & Size $/ \mathrm{mm}^{3}$ & $\circ / 10^{\circ} \mathrm{kgm}^{-3}$ & $\sigma / \mathrm{Scm}^{1}$ \\
\hline A & LSM $/$ ASEC $/ L S M$ & $3 \times 3 \times 20$ & 5.87 & 164 \\
B & LCC/ASEC/LCC & $3 \times 3 \times 20$ & 5.85 & 32 \\
C & LSM & $2 \times 2 \times 20$ & 5.93 & 166 \\
D & LCC & $2 \times 2 \times 20$ & 5.90 & 41 \\
E & LSM+LCC & $2 \times 2 \times 20$ & 3.90 & 10.3 \\
\hline
\end{tabular}

LSM: dense (La0.85 $\left.\mathrm{Sro}_{15}\right)_{0.85} \mathrm{MnO}_{3}$

ASEC: porous ( $\left(\mathrm{La} 0.85 \mathrm{Sr}_{0.15}\right)_{0.85} \mathrm{MnO}_{3}$ for electrical connection. LCC: dense (La0.75Ca0.3) $\mathrm{Cr}_{0.95} \mathrm{O}_{3}$

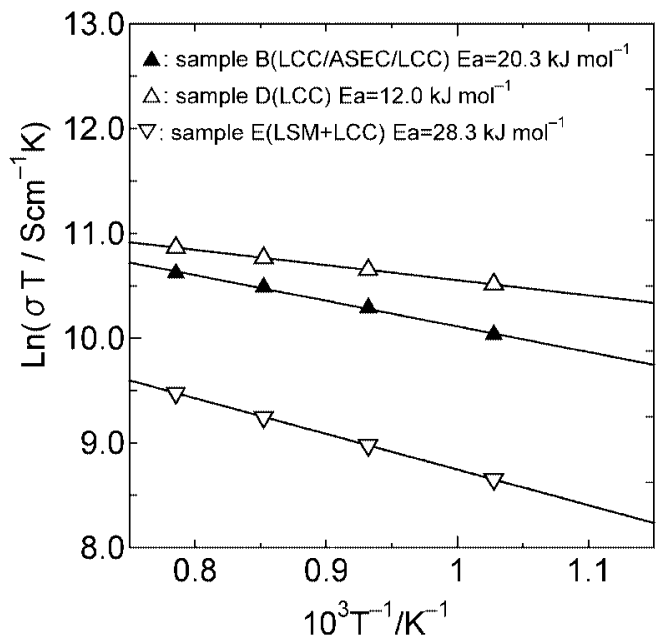

Fig. 7. Electrical conductivity of the samples B, D and E. The sample B is prepared by bonding the dense LCC bulks with the ASEC as an insert layer. The samples D and $\mathrm{E}$ are made of the dense LCC and the LSM + LCC mixture, respectively.

The setup for measuring the contact resistances ${ }^{16)}$ between the LSM bulk and the ASEC, and between the LCC and the ASEC, were shown in Fig. 3. The contact resistances were calculated as Eqs. (1) and (2).

$$
\begin{aligned}
& R_{\text {cont }-(\mathrm{LSM})}=0.5\left(R_{\mathrm{all}(\mathrm{A})}-R_{\mathrm{LSM}}\right) \\
& R_{\text {cont }-(\mathrm{LCC})}=0.5\left(R_{\mathrm{all}(\mathrm{B})}-R_{\mathrm{LCC}}\right)
\end{aligned}
$$




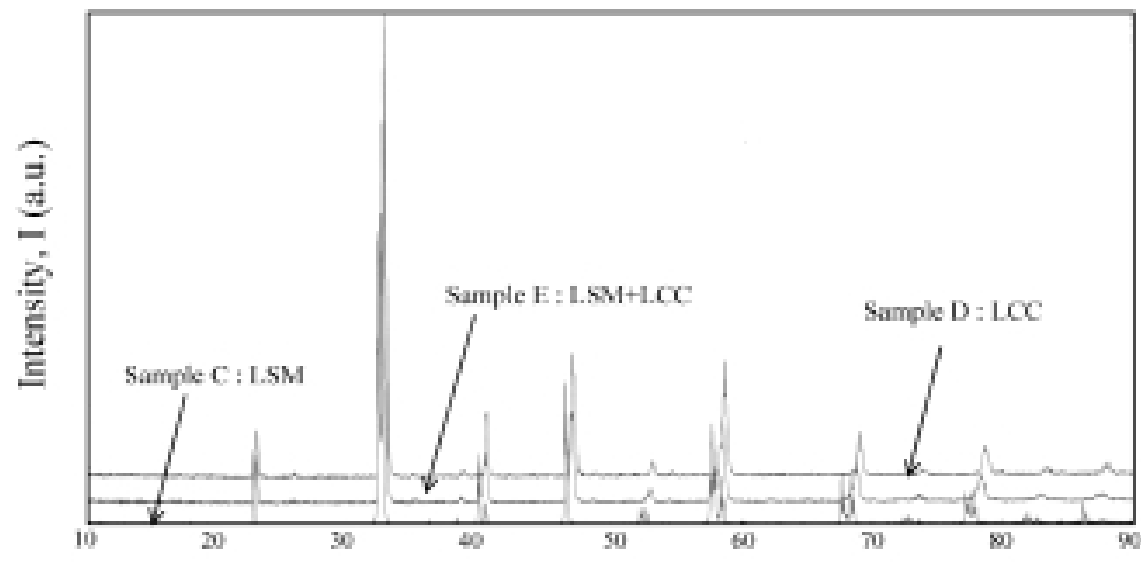

Diffraction Angle, $2 \theta \gamma^{\circ}$

Fig. 8. X-ray diffraction patterns of the LSM, the LSM + LCC mixture and the LCC which were sintered at $1500^{\circ} \mathrm{C}$ in air.

Table 2. Contact Resistance between LSM and ASEC, and between LCC and ASEC at $1000^{\circ} \mathrm{C}$

\begin{tabular}{ccccc}
\hline Sample & Material & $\mathrm{R}_{1} / \mathrm{m} \Omega \mathrm{cm}^{2}$ & $\mathrm{R}_{2} / \mathrm{m} \Omega \mathrm{cm}^{2}$ & $\mathrm{R}_{3} /{\mathrm{m} \Omega \mathrm{cm}^{2}}^{2}$ \\
\hline A & LSM $/$ ASEC & 1.1 & 1.9 & 6.7 \\
B & LCC/ASEC & 4.2 & 5.0 & - \\
\hline
\end{tabular}

$R$ : contact resistance at the interface. Subscript denotes the added compressive stress during the bonding. $\mathrm{R}_{1}: 98 \mathrm{kPa}, \mathrm{R}_{2}$ : $49 \mathrm{kPa}, \mathrm{R}_{3}: 20 \mathrm{kPa}$.

where, $R_{\text {cont-(LSM) }}, R_{\text {all (A) }}$ and $R_{\mathrm{LSM}}$ are contact resistance between the ASEC and the LSM, overall resistance of the bonded sample of LSM/ASEC/LSM, and the resistance of the LSM. It is obvious that the $R_{\text {cont }}$ includes the resistance of the ASEC. Table 2 and Fig. 9 show the results of the calculated contact resistances. The horizontal axis of the figure denotes the compressive stress of the bonding. The contact resistances between the LSM and the ASEC were $6.7 \mathrm{~m} \Omega$. $\mathrm{cm}^{2}, 1.9 \mathrm{~m} \Omega \cdot \mathrm{cm}^{2}, 1.1 \mathrm{~m} \Omega \cdot \mathrm{cm}^{2}$ at the bonding condition of 20 $\mathrm{kPa}, 49 \mathrm{kPa}$, and $98 \mathrm{kPa}$, respectively. The interface between the LCC and the ASEC has higher electric contact resistance than the one between LSM and ASEC. The contact resistances were $5.0 \mathrm{~m} \Omega \cdot \mathrm{cm}^{2}, 4.2 \mathrm{~m} \Omega \cdot \mathrm{cm}^{2}$ at the bonding condition of $49 \mathrm{kPa}$, and $98 \mathrm{kPa}$, respectively. These contact resistances originate from the formation of the perovskite material at the interface, which has a comparatively high electrical resistance.

With the obtained contact resistance at the interface, the $I-R$ drop in the gas separator was estimated. The focused contact point in the gas separator is shown in the Fig. 1 . We used the contact resistance of $1.1 \mathrm{~m} \Omega \cdot \mathrm{cm}^{2}$ for between the LSM and the ASEC, and $4.2 \mathrm{~m} \Omega \cdot \mathrm{cm}^{2}$ for between the LCC and the ASEC. The LCC current passages are $18 \mathrm{~mm}$ in diameter, and twenty four (24) LCC pellets are placed on the separator plate. When the $150 \mathrm{~cm}^{2}$ cell is operated at the current density of $0.3 \mathrm{~A} \mathrm{~cm}^{-2}$, the current of $1.88 \mathrm{~A}$ go through in the each LCC current passage. At the interface between the LSM current collector and the LCC current passage, the $I-R$ loss of $3.9 \mathrm{mV}$ occurs. We have conducted the SOFC power generation tests. After the test, we had a random sampling; cut off the twenty (20) samples from the stack to evaluate the electrical contact. The contact resistance between the LSM and the LCC was around $5 \mathrm{~m} \Omega \cdot \mathrm{cm}^{2}$. No sample had the resistance higher than 10 $\mathrm{m} \Omega \cdot \mathrm{cm}^{2}$. The developed ASEC was very effective to obtain the reliable contact between the LSM current collector and

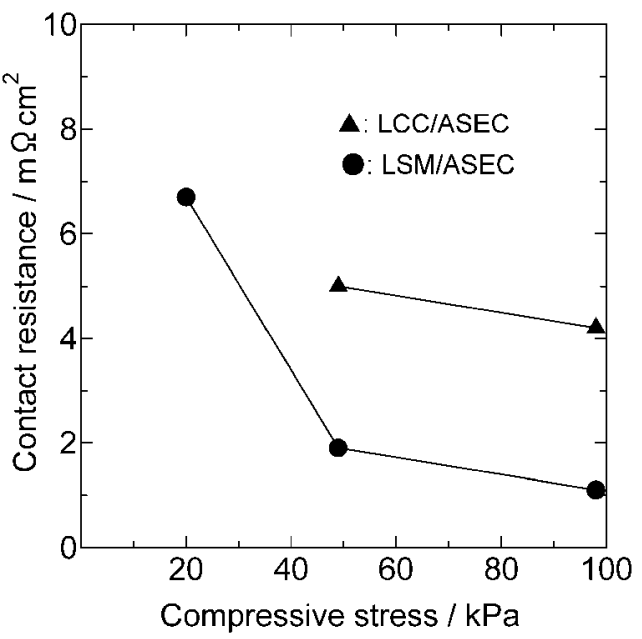

Fig. 9. Contact resistances between the LSM and the ASEC, and between the LCC and ASEC at $1000^{\circ} \mathrm{C}$ in air.

the LCC current passage.

\section{Conclusion}

Aiming at lowering contact resistance between SOFC components, we demonstrated the Air-Side Electrical Connector (ASEC) which deforms easily under the compressive load at high temperature. The ASEC was prepared by soaking the cloth of the carbon fiber with the LSM slurry and firing at $1200^{\circ} \mathrm{C}$. The dense LSM bulks or the LCC bulks were bonded with the ASEC as an intermediate material at $1500^{\circ} \mathrm{C}$. The thickness change of ASEC under the compressive stress was measured. The contact resistances between the LSM and the ASEC, and between the LCC and the ASEC were evaluated. The obtained results lead to the following conclusions.

(1) The ASEC deformed easily at the elevated temperature. Its thickness changed to be $38 \%, 46 \%$, and $58 \%$ of the pre-deformed ones under the stress of $98 \mathrm{kPa}, 49 \mathrm{kPa}$, and $20 \mathrm{kPa}$, respectively.

(2) The contact resistances at $1000^{\circ} \mathrm{C}$ between the LSM and the ASEC, and between the LCC and the ASEC were $1.1 \mathrm{~m} \Omega \cdot \mathrm{cm}^{2}$ and $4.2 \mathrm{~m} \Omega \cdot \mathrm{cm}^{2}$ at the bonding condition of $98 \mathrm{kPa}$, respectively. The estimated $I-R$ drop at the con- 
tact of LSM/LCC was limited as low as $4 \mathrm{mV}$ at the cell current density of $0.3 \mathrm{~A} \mathrm{~cm}^{-2}$. It is efficiently low value for practical use. According to the X-ray diffraction and the electrical resistant measurements, the new perovskite phase was recognized to form at the interface between the LCC and the ASEC.

\section{References}

1) Minh, N. Q., J. Am. Ceram. Soc., Vol. 76, pp. 563-568 (1993).

2) Veyo, S. E., Proc. of the 3rd Internatinal Fuel Cell Conference, pp. 327-332 (1999).

3) Dokiya, M., Ceramics Japan, Vol. 36, pp. 469-471 (2001) [in Japanese].

4) Tachibana, K., Nakashima, H., Nishiyama, H., Aizawa, M., Eguchi, K. and Arai H., Proc. of the 4th Internatinal Symp. on Solid Oxide Fuel Cells, pp. 208-215 (1995).

5) Sakaki., Y, Yoshida, H., Nakanishi, A., Esaki, Y. and Hattori, M., Proc. of the 3rd Internatinal Fuel Cell Conference, pp. 345-348 (1999).

6) Nakanishi, A. and Aiki, H., Ceramics Japan, Vol. 36, pp. 496-498 (2001) [in Japanese].

7) Murata, K., Izumi, M. and Shimotsu, M., J. Ceram. Soc. Japan,
Vol. 107, pp. 1206-1210 (1999) [in Japanese].

8) Murata, K., Izumi, M. and Shimotsu, M., Mitsui Zosen Technical Review, Vol. 154, pp. 6-12 (1995) [in Japanese].

9) Murata, K. and Shimotsu, M., Electrochemistry, Vol. 69, pp. 587-591 (2001).

10) Izumi, M. and Shimotsu, M., J. Ceram. Soc. Japan, Vol. 107, pp. 349-352 (1999) [in Japanese].

11) Yasuda, I. and Hishinuma, M., Proc. of the 4th Internatinal Symp. on Solid Oxide Fuel Cells, pp. 924-933 (1995).

12) Sakai, N., Kawada, T., Yokokawa, H., Dokiya, M. and Kojima, I., J. Am. Ceram. Soc., Vol. 76, pp. 609-616 (1993).

13) Sakai, N., Kawada, T., Yokokawa, H., Dokiya, M. and Iwata, T., J. Mater. Sci., Vol. 25, pp. 4531-4534 (1990).

14) Yasuda, I. and Hikita, T., J. Electrochem. Soc., Vol. 140, pp. 1699-1704 (1993).

15) Katayama, K., Ishihara, T., Ohta, H., Takeuchi, S., Esaki, Y. and Inukai, E., J. Ceram. Soc. Japan, Vol. 97, pp. 1327-1333 (1989).

16) Shundo, H., Shimizu, H., Kusunose, N., Iwata, T., Maruyama, S. and Koseki, K., Proc. of the 2nd Internatinal Symp. on Solid Oxide Fuel Cells, pp. 119-126 (1991). 